\title{
Effects of the Ba Impregnation on Pt Electrode on NO Electrochemical Reduction Mechanism
}

\author{
Xi Wang \\ Jiangsu Investment Management Co., Ltd., Nanjing, China \\ Email address: \\ 175574373@qq.com \\ To cite this article: \\ Xi Wang. Effects of the Ba Impregnation on Pt Electrode on No Electrochemical Reduction Mechanism. International Journal of Economy, \\ Energy and Environment. Vol. 4, No. 2, 2019, pp. 24-32. doi: 10.11648/j.ijeee.20190402.11
}

Received: June 5, 2019; Accepted: July 16, 2019; Published: July 19, 2019

\begin{abstract}
The study investigated the electrochemical reduction performances of $\mathrm{NO}$ and $\mathrm{O}_{2}$ on Pt symmetric electrode with $\mathrm{Ba}$ adsorption layer. The temperature varied from $350^{\circ} \mathrm{C}$ to $550^{\circ} \mathrm{C}$. The experimental $\mathrm{Ba}\left(\mathrm{NO}_{3) 2}\right.$ solution was impregnated in the Pt electrode. For the NO performance, the polarization curves and CV tests showed that the Pt-BaO electrode showed higher electrochemical performance than Pt electrode. EIS results revealed that the $\mathrm{Pt}-\mathrm{BaO}$ electrode exhibited higher activity than the Pt electrode. It was due to the decreased polarization resistance in the low-frequency region that dominated the electrochemical impedance spectra. The increase of temperature strengthened the effect of adsorption layer on NO electrochemical performance. The EIS results were fitted well with the equivalent circuit model indicating that the improved mechanism with the Ba adsorption layer may be related with the $\mathrm{NO}$ oxidation to $\mathrm{NO}_{2}$ on the Pt surface, the formation of $\mathrm{Ba}\left(\mathrm{NO}_{3}\right)_{2}$ in the adsorption layer and the reduction of the reaction path from the direct $\mathrm{Ba}\left(\mathrm{NO}_{3}\right)_{2}$ decomposition.
\end{abstract}

Keywords: Symmetric Electrode, Electrochemical Performance, Electrochemical Impedance Spectra, Equivalent Circuit Model

\section{Introduction}

Nitrogen oxides are the main exhaust pollutants emitted by diesel engines and gasoline engines. These pollutants (mainly NO) are discharged directly into the environment without purification can have a huge impact on the environment [1-3]. It can cause acid rain, photochemical smog. Traditional removal technology of nitrogen oxides is selective catalytic reduction (SCR) technology. The excess of $\mathrm{O}_{2}$ in these pollutants causes the removal of nitrogen oxides incompletely [4-6]. Electrochemical removal of NO by using solid oxide electrolysis cell (SOEC) avoids the produced pollutions such as $\mathrm{CO}, \mathrm{CH}_{\mathrm{x}}$. Besides, it saves the large reducing agents storage system [7-12].

In the electrolysis cathode, $\mathrm{NO}$ can be reduced to $\mathrm{N}_{2}$ and $\mathrm{O}^{2-} . \mathrm{O}^{2-}$ can be transferred to anode and oxidized to $\mathrm{O}_{2}$ under external electric field. Electrochemical reduction of NO can be operated at low temperature range that fits well with the exhausts temperature from the diesel/gasoline engine. Nevertheless, it confronted with the difficulties of NO selectivity improvement and conversion performance in the excess $\mathrm{O}_{2}$ exhausts. An efficient method that has been carried out in previous studies [13-16] is by adding NOx adsorption layer on the electrode to constitute a multi-functional electrode layer. The adsorption layer is also named three-way catalyst (TWC). In this way, NOx can be trapped and stored in the adsorption layer. The NOx selectivity and activity can be strengthened.

Bredikin [17-19] et al studied NO electrochemical performance on the $\mathrm{Pt}$ electrode coated with $\mathrm{NiO} / \mathrm{YSZ}$ composite layer. Results showed that NO conversion can be improved due to the formed nanometer microstructure in the $\mathrm{NiO} / \mathrm{YSZ}$ layer by increasing the reactive cites. The proposed reaction mechanism was that the reduced $\mathrm{Ni}$ metal played the role of transferring oxygen species in the reaction processes. Hamamoto [20] investigated three different NOx adsorption layers of $\mathrm{Na} / \mathrm{Pt} / \mathrm{Al}_{2} \mathrm{O}_{3}, \mathrm{Cs} / \mathrm{Pt} / \mathrm{Al}_{2} \mathrm{O}_{3}, \mathrm{~K} / \mathrm{Pt} / \mathrm{Al}_{2} \mathrm{O}_{3}$ on $\mathrm{NO}$ conversion performances. From the results, it can be concluded that $\mathrm{K} / \mathrm{Pt} / \mathrm{Al}_{2} \mathrm{O}_{3}$ exhibited the best performance and the NO conversion reached $80 \%$. The NO conversion was only $60 \%$ in the blank $\mathrm{Pt}$ electrode without the adsorption layers. Vernoux [21] impregnated $\mathrm{BaO}$ on the $\mathrm{Pt}$ electrode and studied the NOx storage-reduction (NSR) 
process in the $\mathrm{Pt}-\mathrm{BaO} / \mathrm{YSZ}$ cell at $350^{\circ} \mathrm{C}$ and $400^{\circ} \mathrm{C}$. It can be obtained from the results that the NOx storage-reduction process can be characterized in situ. It can be due to the variations of the catalyst potential. Later, he [22] observed electrochemical promotion of catalysis (EPOC) effect on an electrochemically-assisted NSR catalyst electrodes containing $\mathrm{Ba}$ adsorption layer. It was proposed by Vayenas [23]. The principle was that the promoter ions such as $\mathrm{O}^{2-}, \mathrm{K}^{+}$ can be produced. These promoter ions can be electrochemically supplied to the catalyst surface by applying polarization between the catalyst electrode and the counter electrode. The catalytic performance can be changed by the modification of the catalyst work function. Conclusions were made that Ba containing catalyst showed better activity than $\mathrm{Ba}$ free electrode. An electromotive force(EMF) was formed between the nanometer $\mathrm{Pt}$ and $\mathrm{Rh}$ electrodes. This EMF induced the self-sustained electrochemical promotion effect that in turn enhanced the catalytic activity. The promotion effect was named as Non-Faraday Electrochemical Modification of Catalytic Activity Effect(NEMCA) [24].

Traulsen et al [25] added $\mathrm{KNO}_{3}$ and $\mathrm{MnOx}$ adsorption layer in the LSM/GDC electrode. Cyclic voltammetry (CV) and electrochemical impedance spectroscope (EIS) experiment results demonstrated that $\mathrm{KNO}_{3}$ can be used for NOx storage but MnOx. Both the impregnation of $\mathrm{KNO}_{3}$ and $\mathrm{MnOx}$ can cause the decrease of the polarization resistance related to the formation of $\mathrm{NO}_{2}$ from $\mathrm{NO}$ oxidation. They [26-27] also applied $\mathrm{K}_{2} \mathrm{O}, \mathrm{BaO}$ on the $\mathrm{La}_{0.85} \mathrm{Sr}_{0.15} \mathrm{FeO}_{3} / \mathrm{Ce}_{0.9^{-}}$ $\mathrm{Gd}_{0.1} \mathrm{O}_{1.95}$ (LSF-GDC) and $\mathrm{La}_{0.85} \mathrm{Sr}_{0.15} \mathrm{MnO}_{3} / \mathrm{Ce}_{0.9} \mathrm{Gd}_{0.1} \mathrm{O}_{1.95}$ (LSM-GDC) composite electrodes respectively based on the GDC electrolyte cell stacks. Results showed that high NOx conversion can be obtained with the NOx adsorption layer between $300^{\circ} \mathrm{C}$ and $500^{\circ} \mathrm{C}$. Shao [28] later investigated NO electrochemical reduction characteristics on LSM-GDC electrode containing $\mathrm{Ba} / \mathrm{Pt} / \mathrm{Al}_{2} \mathrm{O}_{3}$ adsorption layer in the direct current (DC) and square wave (SV) electrolysis. The NOx trapping and reduction rates can be balanced in the SV electrolysis indicating the further improvement. She [29] further demonstrated that the improvement mechanism was to promote the adsorption and surface diffusion of NOx species near/at the triple phase boundary (TPB) and the $\mathrm{K} / \mathrm{Pt} / \mathrm{Al}_{2} \mathrm{O}_{3}$ layer showed better performance than the $\mathrm{Ba} / \mathrm{Pt} / \mathrm{Al}_{2} \mathrm{O}_{3}$ layer toward $\mathrm{NO}$ reduction. According to the above studies, the further reaction mechanism for $\mathrm{NO}$ electrochemical reduction in the adsorption layer was not clear. And the electrochemical performance of NO reduction required further investigation to illustrate the interior reaction mechanism.

This paper investigated the electrochemical reduction of $\mathrm{NO}$ and $\mathrm{O}_{2}$ on symmetric Pt electrode by adding $\mathrm{Ba} \mathrm{NOx}$ adsorbents. Two cells were prepared and tested: single $\mathrm{Pt}$ electrode, Pt electrode with $\mathrm{Ba}\left(\mathrm{NO}_{3}\right)_{2}$ impregnation (Pt-BaO electrode). Linear sweep voltammetry, cyclic voltammetry (CV) and EIS measurements were carried out between $350^{\circ} \mathrm{C}$ and $550^{\circ} \mathrm{C}$. Detailed reaction processes were characterized by EIS fitted results in different frequency range.

\section{Experiment Tests}

\subsection{Cell Preparation}

Two symmetric cells Pt/YSZ/Pt were prepared coating with Pt electrode by screen printing method and sintered at $900^{\circ} \mathrm{C}$ for $1 \mathrm{~h}$ in air. And the Pt electrode area was $3.14 \mathrm{~cm}^{2}$. YSZ was used as the electrolyte. One cell was impregnated with $\mathrm{Ba}$ $\left(\mathrm{NO}_{3}\right)_{2}$ solution for $1 \mathrm{~min}$ by the suction filtration of the pump. The concentration of the $\mathrm{Ba}\left(\mathrm{NO}_{3}\right)_{2}$ was $0.32 \mathrm{~mol} / \mathrm{L}$. The $\mathrm{Ba}$ impregnation cell was sintered at $700^{\circ} \mathrm{C}$ for $1 \mathrm{~h}$ after it was dried in air.

\subsection{Experiment Measurements}

The electrochemical experiments were tested by ZAHNER (Germany) from $350^{\circ} \mathrm{C}$ to $550^{\circ} \mathrm{C}$. The EIS tests were recorded in the frequency range of $100 \mathrm{kHz}$ to $0.1 \mathrm{~Hz}$ with the amplitude of $10 \mathrm{mV}$. For the linear sweep voltammetry measurements, the voltage was set from $2 \mathrm{~V}$ to $0 \mathrm{~V}$ at the scanning rate of $20 \mathrm{mV} / \mathrm{s}$. And CV tests scanned from $0.5 \mathrm{~V}$ to $-0.5 \mathrm{~V}$ at the rate of $10 \mathrm{mV} / \mathrm{s}$. The inlet gases were composed of $800 \mathrm{ppm} \mathrm{NO}, 8 \% \mathrm{O}_{2}$ and $\mathrm{Ar}$ was used as the carrier gas. The total flow rate was set at $100 \mathrm{ml} / \mathrm{min}$. All the gas concentrations were chosen according to the engine exhausts. The EIS measurements fitted with the equivalent circuit model (ECM) were analyzed by the ZsimpWin software. The EIS results analyzed by the equivalent circuit model proved to be important for the understanding of the strengthened selectivity mechanism of NO. This analyzing method was adopted by Shao [30] in the thesis.
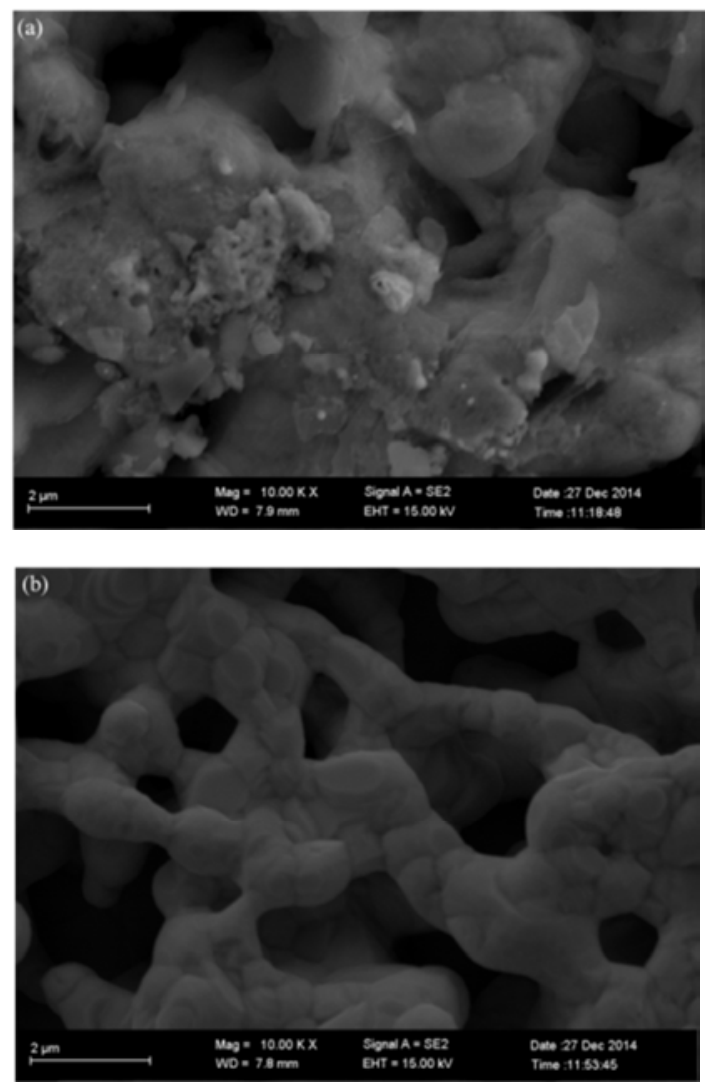

Figure 1. Surface microstructure images for the two electrodes: (a) $\mathrm{Ba}$ impregnated electrode (b) Non-impregnated Pt electrode. 
Both of the two types of the cell microstructure were characterized by scanning electron microscope (SEM) after testing. It can be shown from the figure 1 (a) that the SEM image of the $\mathrm{Ba}$ impregnated cell presented small and distinct $\mathrm{BaO}$ particles over the $\mathrm{Pt}$ electrode surface according to the energy dispersive spectrometer (EDS) results. The blank Pt electrode presented regular porous microstructure.

\section{Results and Discussion}

\subsection{Current Voltage (I-V) Characteristics}

Figure 2 gives the polarization curves of the $\mathrm{NO}$ electrochemical reduction on $\mathrm{Pt}$ electrode and $\mathrm{Pt}-\mathrm{BaO}$ electrode at $440^{\circ} \mathrm{C}$ and $550^{\circ} \mathrm{C}$. The tests were conducted in $800 \mathrm{ppm}$ NO. Ar was the carrier gas. At higher temperatures and voltages $(1.25 \mathrm{~V}$ to $2 \mathrm{~V})$, it could be observed that the Ba impregnated electrode exhibited higher electrochemical performance than the blank Pt electrode. It was explained that NO can be stored in the $\mathrm{Ba}$ active sites in the adsorption layer in the form of $\mathrm{Ba}$ $\left(\mathrm{NO}_{3}\right)_{2}$. Thus, the reaction kinetics on the Pt-BaO surface was strengthened. And the electrochemical reaction processes can be accelerated by the reduction of reaction path. Here refered to the $\mathrm{Ba}\left(\mathrm{NO}_{3}\right)_{2}$ decomposition to $\mathrm{N}_{2}$ directly with external electrical field. The reaction phenomenon was similar discovered by Shao [28-29] in the experiments.

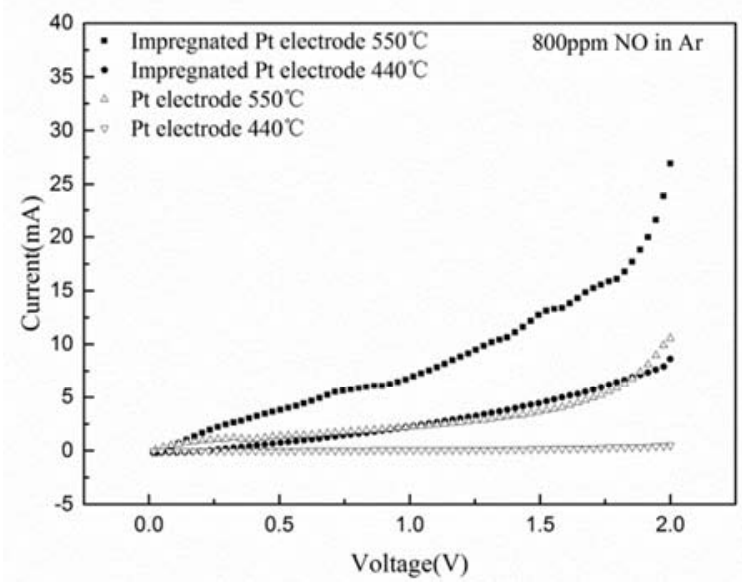

Figure 2. Polarization curves of $800 \mathrm{ppm} \mathrm{NO}$ in $\mathrm{Ar}$ on Pt-Ba electrode and Pt electrode at $550^{\circ} \mathrm{C}$ and $440^{\circ} \mathrm{C}$.

\subsection{Cyclic Voltage Measurements}

Figure 3 to 6 show the electrochemical performances of the $\mathrm{Pt}$ electrode and $\mathrm{Pt}-\mathrm{BaO}$ electrode in $8 \% \mathrm{O}_{2}, 800 \mathrm{ppmNO}$ atmospheres by cyclic voltammetry with the temperature varying from $350^{\circ} \mathrm{C}$ to $450^{\circ} \mathrm{C}$. The sweep rate was set at $10 \mathrm{mV} / \mathrm{s}$. As shown in figure 3 and 4 , the Pt electrode showed better activity and selectivity in $\mathrm{O}_{2}$ atmosphere than in pure $\mathrm{NO}$ atmosphere at $440^{\circ} \mathrm{C}$. A small hysteresis was observed in both two atmospheres. When changed the sweep direction from negative voltage to anodic voltage, the reduction peaks of $\mathrm{NO}$ and $\mathrm{O}_{2}$ were observed. And the $\mathrm{NO}$ reduction peak appeared earlier than $\mathrm{O}_{2}$. The increase of the current with temperature in $\mathrm{O}_{2}$ atmosphere was more significant than that in pure $\mathrm{NO}$ atmosphere.

It can be obtained from figure 5 and 6 that $\mathrm{Pt}-\mathrm{BaO}$ electrode was superior to the blank $\mathrm{Pt}$ electrode in $800 \mathrm{ppm} \mathrm{NO}$ atmosphere due to the storage of NO in the adsorption layer. The effect of the Ba adsorption layer became more significant as the temperature increased to $440^{\circ} \mathrm{C}$. It can be concluded that the increase of activity with temperature on the Pt-BaO electrode was more obviously in NO atmosphere compared with the Pt electrode.

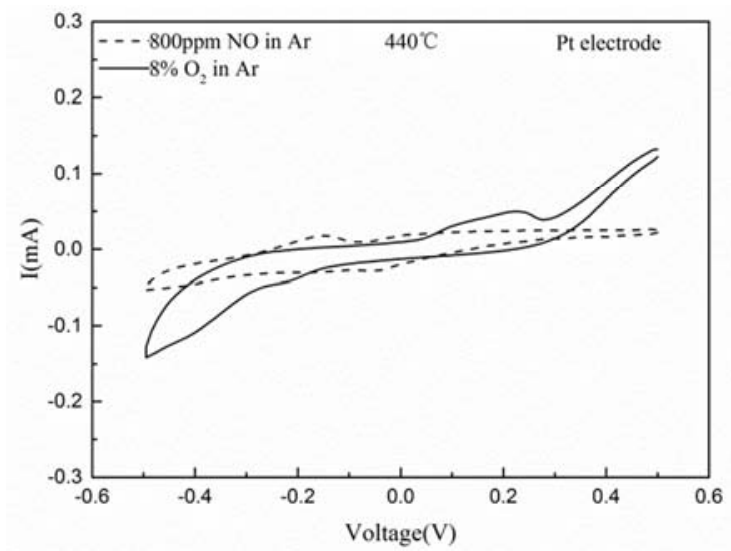

Figure 3. Cyclic voltammograms on Pt electrode in different atmospheres at $440^{\circ} \mathrm{C}$.

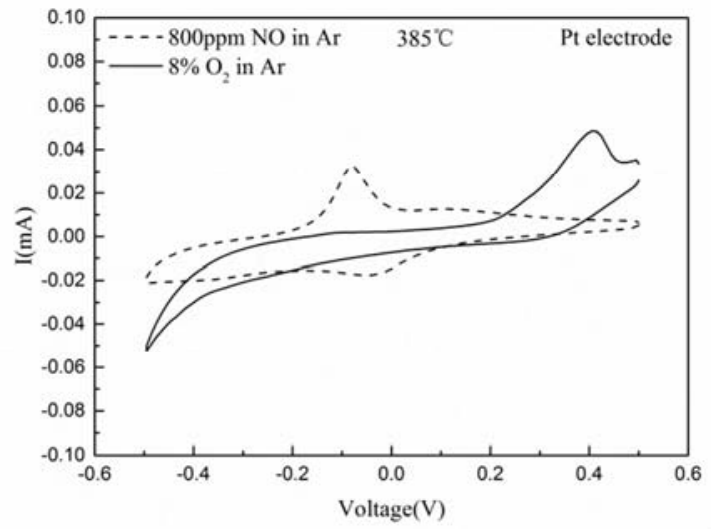

Figure 4. Cyclic voltammograms on Pt electrode in different atmospheres at $385^{\circ} \mathrm{C}$.

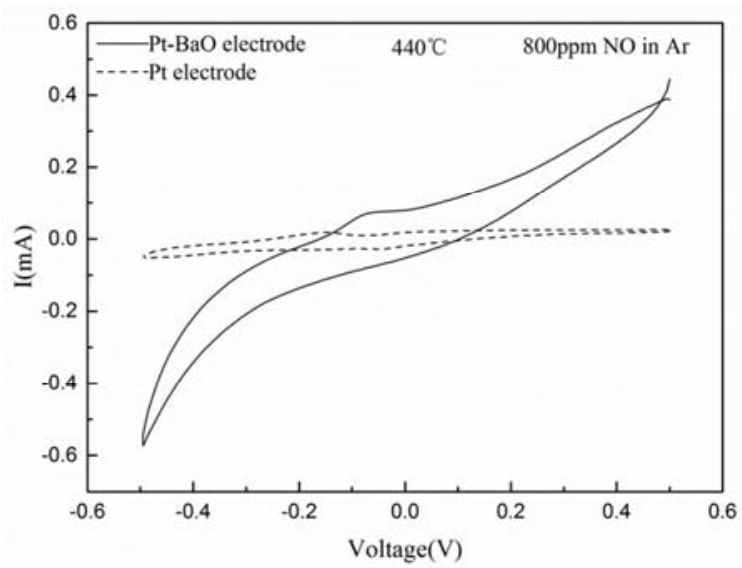

Figure 5. Cyclic voltammograms of 800ppm NO in Ar on Pt-BaO electrode and Pt electrode at $440^{\circ} \mathrm{C}$. 


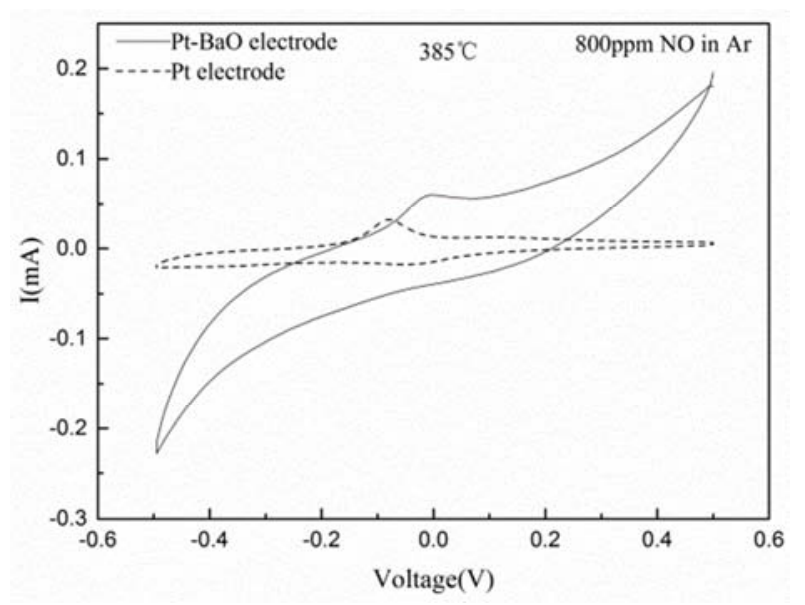

Figure 6. Cyclic voltammograms of 800ppm NO in $\mathrm{Ar}$ on Pt-BaO electrode and Pt electrode at $385^{\circ} \mathrm{C}$.

\subsection{EIS Results}

The EIS measurements in different atmospheres were conducted on the two types of the cells from $350^{\circ} \mathrm{C}$ to $550^{\circ} \mathrm{C}$ at open circuit voltage $(\mathrm{OCV})$ that were shown from figure 7 to figure 10. Three different gas atmospheres were investigated: 800ppm NO with $8 \% \mathrm{O}_{2}, 800 \mathrm{ppm} \mathrm{NO}$ and $8 \% \mathrm{O}_{2}$. Ar was used as the carrier gas. It can be seen from figure 7 to figure 10 that the $\mathrm{Pt}-\mathrm{BaO}$ electrode presented lower resistance than the $\mathrm{Pt}$ electrode in three atmospheres with the temperature ranging from $350^{\circ} \mathrm{C}$ to $550^{\circ} \mathrm{C}$. At high temperature of $550^{\circ} \mathrm{C}$ and $440^{\circ} \mathrm{C}$, the resistance in $\mathrm{O}_{2}$ appeared larger than in $\mathrm{NO}$ with $\mathrm{O}_{2}$ mixtures on two cells which was close to the results conducted by Shao [29]. This may be due to the formation of $\mathrm{NO}_{2}$ from $\mathrm{NO}$ oxidation with $\mathrm{O}_{2}$ on $\mathrm{Pt}$ electrode surface. As temperature decreased, the impedance spectra in $\mathrm{O}_{2}$ atmosphere showed the largest. And the spectra in three atmospheres became close to each other on two cells. The resistance in $\mathrm{NO}$ with $\mathrm{O}_{2}$ atmosphere showed the lowest in Pt-BaO electrode which was related to the $\mathrm{NO}_{2}$ formation from $\mathrm{NO}$ oxidation process that decreased the activation energy. The formation of $\mathrm{Ba}\left(\mathrm{NO}_{3}\right)_{2}$ from $\mathrm{NO}$ or $\mathrm{NO}_{2}$ accelerated the reaction rates. The Warburg diffusion process was observed in low frequency region. The phenomenon became obvious at lower temperature. This was related to the increased diffusion resistance at lower temperatures.

As shown in figure 8 to 10 , the decrease of temperature increased the resistances in three atmospheres on both two cells. And the observation was similar to the phenomenon in figure 7. The impedance spectra in $\mathrm{NO}$ with $\mathrm{O}_{2}$ showed similar characteristics compared with pure $\mathrm{O}_{2}$ atmosphere on two cells. To be different, the resistances in three atmospheres on $\mathrm{Pt}-\mathrm{BaO}$ electrode were close to each other with the decrease of the temperature. The resistances in $\mathrm{O}_{2}$ atmosphere exhibited the largest on two electrodes. And the resistance in $\mathrm{NO}$ and $\mathrm{O}_{2}$ mixtures exhibited smaller compared with the resistance in $\mathrm{O}_{2}$ atmosphere. In a word, the electrochemical performance on $\mathrm{Pt}-\mathrm{BaO}$ electrode was superior to that on $\mathrm{Pt}$ electrode. The storage of $\mathrm{NOx}$ in the form of $\mathrm{Ba}\left(\mathrm{NO}_{3}\right)_{2}$ in active sites or the direct electrolysis of $\mathrm{Ba}\left(\mathrm{NO}_{3}\right)_{2}$ in external electric field can enhance the reactivity and selectivity of NO reduction performances.
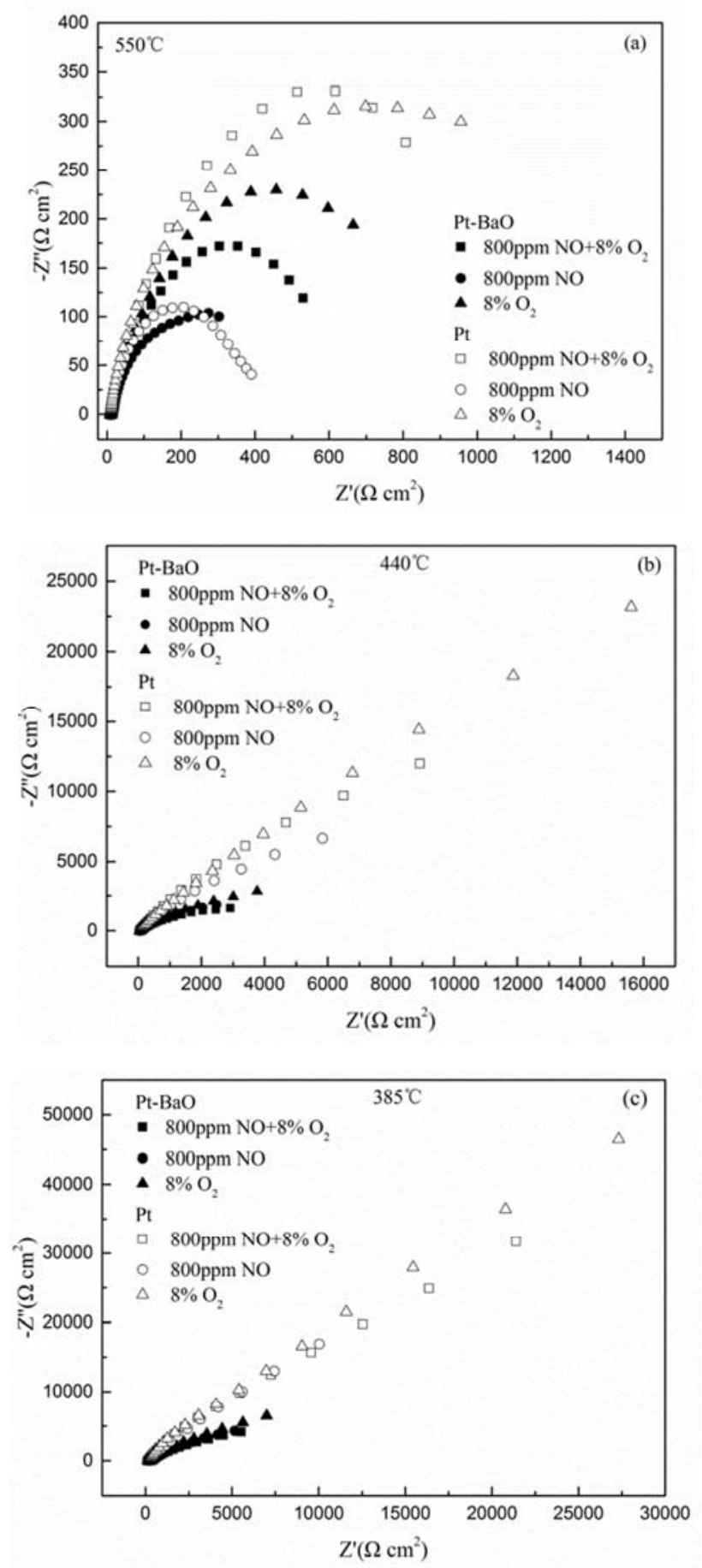

Figure 7. EIS for Pt-BaO electrode and Pt electrode in different atmospheres from $350^{\circ} \mathrm{C}$ to $550^{\circ} \mathrm{C}$ : (a) $550^{\circ} \mathrm{C}$; (b) $440^{\circ} \mathrm{C}$; (c) $385^{\circ} \mathrm{C}$. 


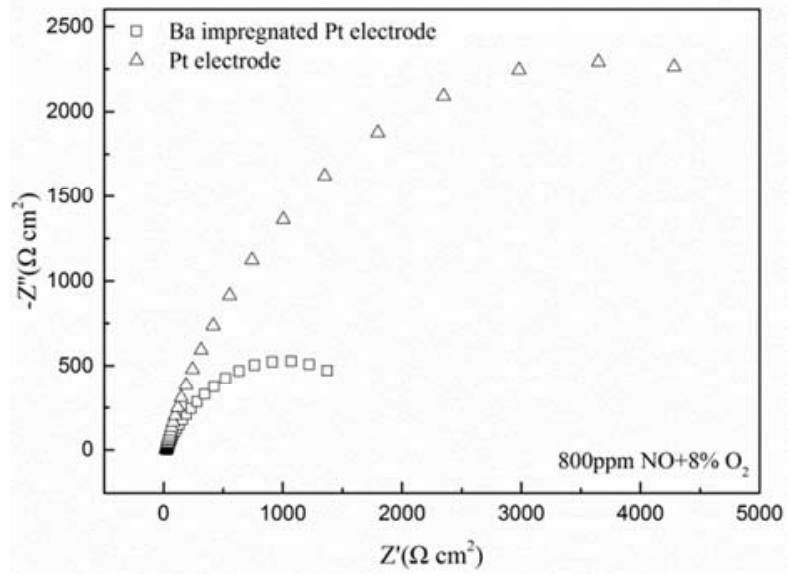

Figure 8. EIS for Pt-BaO electrode and Pt electrode in 800ppm NO with $8 \%$ $\mathrm{O}_{2}$ at $495^{\circ} \mathrm{C}$.

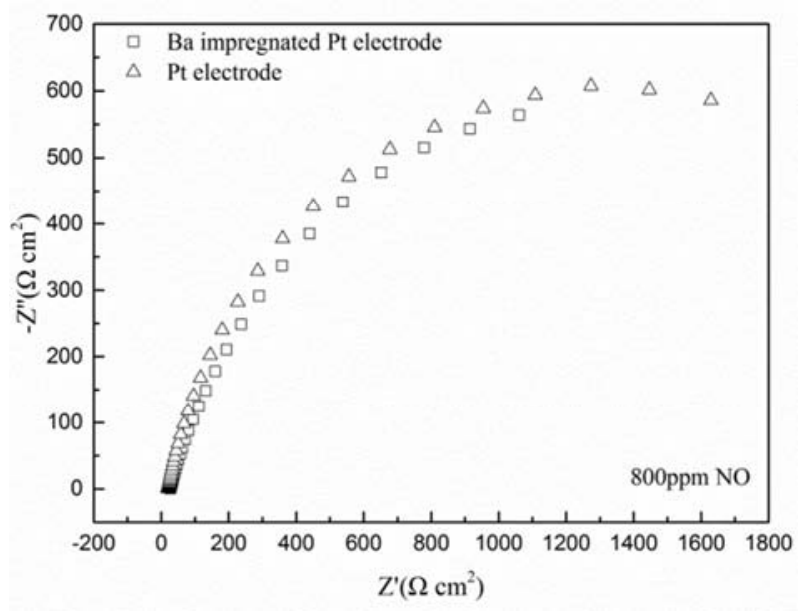

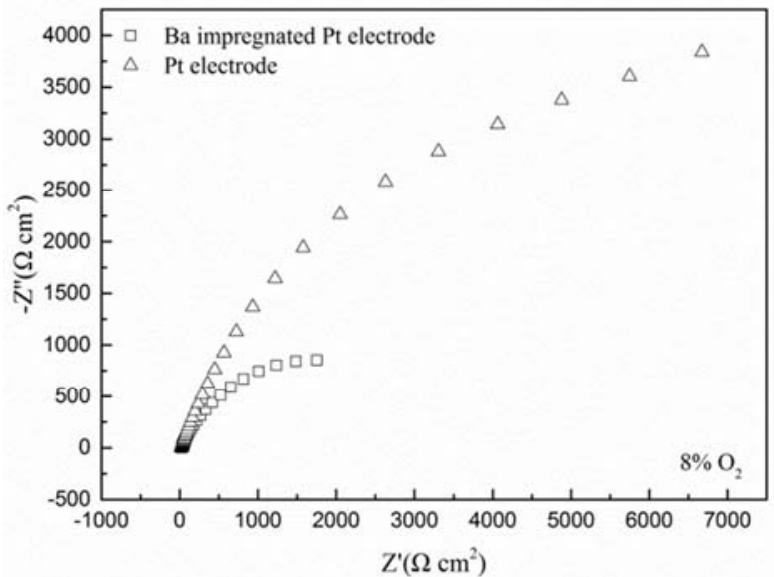

Figure 10. EIS for Pt-BaO electrode and Pt electrode in $8 \% \mathrm{O}_{2}$ at $495^{\circ} \mathrm{C}$

\subsection{EIS Results Fitting to the Equivalent Circuit Model}

An equivalent circuit model contained electrolyte serial resistance Rs (relative to the conductivity of the electrolyte), serial RC elements were used for fitting the impedance spectra by experiments. A polarization resistance is in parallel with a capacitance $\mathrm{C}$. In the nonlinear system, the capacitance can be substituted as the constant phase element (CPE). Shao [30] also adopted this similar model for analyzing the reaction mechanism of the NO electrochemical reaction. The constituent elements of the model were different according to different reaction processes that occurred. It varied from each other according to the experiment results conducted by different researchers.

The schematic of the equivalent circuit model can be showed in figure 11: one serial resistance Rs and $3 \mathrm{RC}$ elements.

Figure 9. EIS for Pt-BaO electrode and Pt electrode in 800 ppm NO at $495^{\circ} \mathrm{C}$.

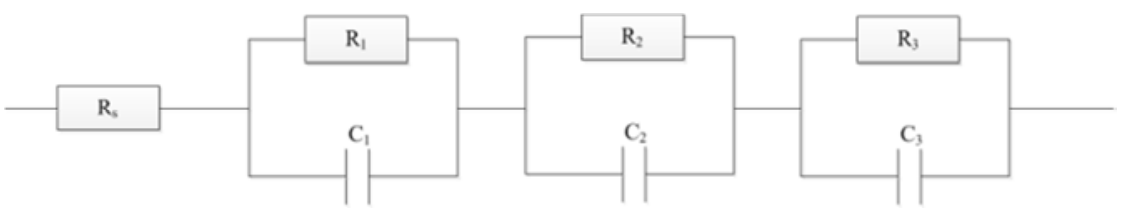

Figure 11. Schematic of the equivalent circuit model.

The impedance for the constant phase element can be written as follows:

$$
Z=\frac{1}{j w Y_{0}}
$$

$Y_{0}$ is the admittance of the impedance. The equivalent capacitance of the capacitance element $(\mathrm{C})$ can be expressed as $C_{\mathrm{w}}$ :

$$
C_{w}=Y_{0}
$$

The summit frequency of the semicircle can be expressed as follows:

$$
f_{m}=\frac{1}{2 \pi R C_{w}}
$$

The activation energy $E$ of the reaction processes can be calculated as follows:

$$
\delta=\delta_{0} \exp \left(-\frac{E}{k_{B} T}\right)
$$

$\delta$ represents the electrical conductivity and $\delta_{0}$ is the pre-exponential factor. $k_{B}\left(1.38 \times 10^{-23} \mathrm{~J} / \mathrm{K}\right)$ is the Boltzmann constant. $T$ is the absolute temperature $(\mathrm{K})$.

The characteristics of the impedance spectra from the fitted results in three different atmospheres from $350^{\circ} \mathrm{C}$ to $550^{\circ} \mathrm{C}$ were listed in Table 1 to 6 on two cells. The polarization resistances were composed of $R_{1}, R_{2}$ and $R_{3} . C_{w}$ was the value of the capacitance element. As temperature decreased, the capacitance in three arcs decreased especially in arc 1. The capacitances in three different arcs at the same temperature were close to each other. 
Table 1. ECM results of Pt electrode in $800 \mathrm{ppm} \mathrm{NO}$ and $8 \% \mathrm{O}_{2}$.

\begin{tabular}{|c|c|c|c|c|c|c|c|}
\hline \multirow{2}{*}{$\mathrm{T}\left({ }^{\circ} \mathrm{C}\right)$} & \multirow{2}{*}{$\mathbf{R}_{\mathrm{s}}\left(\boldsymbol{\Omega} \mathbf{m}^{2}\right)$} & \multicolumn{3}{|c|}{$R_{n}\left(\Omega m^{2}\right)$} & \multicolumn{3}{|c|}{$C_{w}\left(\times 10^{-4} \mathrm{~F} \mathrm{~cm}^{-2}\right)$} \\
\hline & & $\mathbf{R}_{1}$ & $\mathbf{R}_{2}$ & $\mathbf{R}_{3}$ & $\mathrm{C}_{1}$ & $\mathrm{C}_{2}$ & $\mathrm{C}_{3}$ \\
\hline 550 & 9.541 & 12.77 & 121.5 & 694.7 & 0.98 & 2.273 & 5.907 \\
\hline 495 & 22.14 & 28.87 & 558.9 & 4560 & 0.5127 & 0.7521 & 1.341 \\
\hline 440 & 62.93 & 63.63 & 1133 & $2.331 \times 10^{4}$ & 0.2134 & 0.492 & 0.7341 \\
\hline 385 & 167.4 & 95.79 & 3955 & $6.318 \times 10^{4}$ & 0.05818 & 0.1645 & 0.2982 \\
\hline
\end{tabular}

Table 2. ECM results of Pt electrode in 800ppm NO.

\begin{tabular}{|c|c|c|c|c|c|c|c|}
\hline \multirow{2}{*}{$\mathbf{T}\left({ }^{\circ} \mathrm{C}\right)$} & \multirow{2}{*}{$\mathbf{R}_{\mathbf{s}}\left(\boldsymbol{\Omega} \mathbf{m}^{2}\right)$} & \multicolumn{3}{|c|}{$R_{n}\left(\Omega m^{2}\right)$} & \multicolumn{3}{|c|}{$\mathrm{C}_{\mathrm{w}}\left(\times 10^{-4} \mathrm{~F} \mathrm{~cm}^{-2}\right)$} \\
\hline & & $\mathbf{R}_{1}$ & $\mathbf{R}_{\mathbf{2}}$ & $\mathbf{R}_{3}$ & $\mathrm{C}_{1}$ & $\mathbf{C}_{2}$ & $\mathrm{C}_{3}$ \\
\hline 550 & 9.381 & 12.33 & 118.7 & 219 & 0.658 & 0.9818 & 4.649 \\
\hline 495 & 21.87 & 35.09 & 444.8 & 1246 & 0.5409 & 0.8678 & 3.787 \\
\hline 440 & 58.66 & 52.85 & 884.5 & $1.219 \times 10^{4}$ & 0.3709 & 0.7384 & 1.263 \\
\hline 385 & 165.7 & 99.17 & 1476 & $3.507 \times 10^{4}$ & 0.0651 & 0.3469 & 0.5994 \\
\hline
\end{tabular}

Table 3. ECM results of Pt electrode in $8 \% \mathrm{O}_{2}$.

\begin{tabular}{llllllll}
\hline \multirow{2}{*}{$\mathbf{T}\left({ }^{\circ} \mathbf{C}\right)$} & \multirow{2}{*}{$\mathbf{R}_{\mathbf{s}}\left(\mathbf{\Omega} \mathbf{~ m}^{\mathbf{2}}\right)$} & $\mathbf{R}_{\mathbf{n}}\left(\mathbf{\Omega} \mathbf{~ m}^{\mathbf{2}}\right)$ & & & $\mathbf{C}_{\mathbf{w}}\left(\times \mathbf{1 0} \mathbf{0}^{-4} \mathbf{F} \mathbf{c m}^{-2}\right)$ & \\
\cline { 3 - 8 } & & $\mathbf{R}_{\mathbf{1}}$ & $\mathbf{R}_{\mathbf{2}}$ & $\mathbf{R}_{\mathbf{3}}$ & $\mathbf{C}_{\mathbf{1}}$ & $\mathbf{C}_{\mathbf{2}}$ & $\mathbf{C}_{\mathbf{3}}$ \\
\hline 550 & 9.699 & 21.56 & 270.3 & 676.3 & 0.607 & 0.8748 & 5.21 \\
495 & 23.41 & 49.24 & 847.8 & 6902 & 0.1105 & 0.2519 & 0.6493 \\
440 & 57.39 & 151.3 & 2629 & $4.572 \times 10^{4}$ & 0.1426 & 0.1997 & 0.4056 \\
385 & 175.4 & 104.4 & 5199 & $1.014 \times 10^{5}$ & 0.042 & 0.1175 & 0.223 \\
\hline
\end{tabular}

Table 4. ECM results of Pt-BaO electrode in 800ppm $\mathrm{NO}$ and $8 \% \mathrm{O}_{2}$.

\begin{tabular}{|c|c|c|c|c|c|c|c|}
\hline \multirow{2}{*}{$\mathrm{T}\left({ }^{\circ} \mathrm{C}\right)$} & \multirow{2}{*}{$\mathbf{R}_{\mathrm{s}}\left(\mathbf{\Omega} \mathbf{m}^{2}\right)$} & \multicolumn{3}{|c|}{$R_{n}\left(\Omega m^{2}\right)$} & \multicolumn{3}{|c|}{$\mathrm{C}_{\mathrm{w}}\left(\times 10^{-4} \mathrm{~F} \mathrm{~cm}^{-2}\right)$} \\
\hline & & $\mathbf{R}_{1}$ & $\mathbf{R}_{\mathbf{2}}$ & $\mathbf{R}_{3}$ & $\mathrm{C}_{1}$ & $\mathrm{C}_{2}$ & $\mathrm{C}_{3}$ \\
\hline 550 & 12 & 13.78 & 105.5 & 381 & 0.7519 & 1.875 & 6.72 \\
\hline 495 & 28.95 & 30.31 & 272.7 & 1108 & 0.5027 & 1.127 & 3.873 \\
\hline 440 & 82.78 & 56.72 & 587.5 & 2968 & 0.2465 & 0.708 & 2.417 \\
\hline 385 & 239.7 & 94.8 & 835.2 & 6924 & 0.0029 & 0.398 & 1.224 \\
\hline
\end{tabular}

Table 5. ECM results of Pt-BaO electrode in $800 \mathrm{ppm} N O$.

\begin{tabular}{llllllll}
\hline \multirow{2}{*}{$\mathbf{T}\left({ }^{\circ} \mathbf{C}\right)$} & \multirow{2}{*}{$\mathbf{R}_{\mathbf{s}}\left(\mathbf{\Omega} \mathbf{~ m}^{2}\right)$} & $\mathbf{R}_{\mathbf{n}}\left(\mathbf{\Omega} \mathbf{~ m}^{\mathbf{2}}\right)$ & \multicolumn{5}{c}{$\mathbf{C}_{\mathbf{w}}\left(\times \mathbf{1 0}^{-4} \mathbf{F} \mathbf{~ m}^{-2}\right)$} \\
\cline { 3 - 8 } & $\mathbf{R}_{\mathbf{1}}$ & $\mathbf{R}_{\mathbf{2}}$ & $\mathbf{R}_{\mathbf{3}}$ & $\mathbf{C}_{\mathbf{1}}$ & $\mathbf{C}_{\mathbf{2}}$ & $\mathbf{C}_{\mathbf{3}}$ \\
\hline 550 & 11.66 & 12.98 & 93.21 & 208.3 & 1.326 & 2.241 & 3.522 \\
495 & 28.52 & 30.84 & 251.6 & 1049 & 0.802 & 2.022 & 6.891 \\
440 & 81.57 & 64.43 & 560.3 & 3291 & 0.464 & 1.215 & 3.436 \\
385 & 232.5 & 91.53 & 776.8 & 7207 & 0.0028 & 0.4399 & 1.299 \\
\hline
\end{tabular}

Table 6. ECM results of Pt-BaO electrode in $8 \% \mathrm{O}_{2}$.

\begin{tabular}{|c|c|c|c|c|c|c|c|}
\hline \multirow{2}{*}{$\mathbf{T}\left({ }^{\circ} \mathbf{C}\right)$} & \multirow{2}{*}{$\mathbf{R}_{\mathrm{s}}\left(\boldsymbol{\Omega} \mathbf{m}^{2}\right)$} & \multicolumn{3}{|l|}{$R_{n}\left(\Omega m^{2}\right)$} & \multicolumn{3}{|c|}{$\mathrm{C}_{\mathrm{w}}\left(\times 10^{-4} \mathrm{~F} \mathrm{~cm}^{-2}\right)$} \\
\hline & & $\mathbf{R}_{1}$ & $\mathbf{R}_{\mathbf{2}}$ & $\mathbf{R}_{\mathbf{3}}$ & $\mathrm{C}_{1}$ & $\mathrm{C}_{2}$ & $\mathrm{C}_{3}$ \\
\hline 550 & 11.87 & 14.31 & 120.1 & 507.3 & 0.8713 & 2.101 & 6.811 \\
\hline 495 & 29.01 & 31.11 & 317.6 & 1652 & 0.5392 & 1.255 & 3.781 \\
\hline 440 & 81.98 & 59.69 & 670.9 & 4785 & 0.2579 & 0.7463 & 2.078 \\
\hline 385 & 233.2 & 96.86 & 950.4 & $1.061 \times 10^{4}$ & 0.0035 & 0.3323 & 0.93 \\
\hline
\end{tabular}

As was shown in Tables 7 and 8, the summit frequencies at different temperatures were given. The arc 1 relative to the high frequency process ranged from $10 \mathrm{~Hz}$ to $1 \times 10^{4} \mathrm{~Hz}$. The middle frequencies were from $1 \mathrm{~Hz}$ to $10 \mathrm{~Hz}$ and low frequencies varied from $0.01 \mathrm{~Hz}$ to $1 \mathrm{~Hz}$. The activation energy values in $\mathrm{Pt}-\mathrm{BaO}$ electrode were lower than the Pt electrode in three arcs. Arc 1 showed the lowest activation energy and arc 3 showed the largest.

Table 7. The summit frequencies of the fitted arcs in EIS results in $800 \mathrm{ppm} \mathrm{NO}$ with $8 \% \mathrm{O}_{2}$ on Pt electrode.

\begin{tabular}{|c|c|c|c|c|c|c|}
\hline \multirow[t]{3}{*}{ Arcs in EIS } & \multirow[t]{3}{*}{ Frequency Hz) } & \multicolumn{4}{|l|}{$f_{m}(\mathrm{~Hz})$} & \multirow[t]{2}{*}{$\mathrm{E}(\mathrm{eV})$} \\
\hline & & \multicolumn{4}{|l|}{$\mathbf{P t}$} & \\
\hline & & $550^{\circ} \mathrm{C}$ & $495^{\circ} \mathrm{C}$ & $440^{\circ} \mathrm{C}$ & $385^{\circ} \mathrm{C}$ & \\
\hline 1(high) & $10 \sim 10^{4}$ & 127.24 & 107.6 & 117.27 & 285.72 & 0.574 \\
\hline 2(middle) & $1 \sim 10$ & 5.77 & 3.79 & 2.86 & 2.45 & 0.941 \\
\hline 3 (low) & $0.01 \sim 1$ & 0.39 & 0.26 & 0.09 & 0.08 & 1.273 \\
\hline
\end{tabular}


Table 8. The summit frequencies of the fitted arcs in EIS results in 800ppm NO with $8 \% \mathrm{O}_{2}$ on Pt-BaO electrode.

\begin{tabular}{|c|c|c|c|c|c|c|}
\hline \multirow{3}{*}{ Arcs in EIS } & \multirow{3}{*}{ Frequency $(\mathrm{Hz})$} & \multicolumn{4}{|c|}{$f_{m}(\mathrm{~Hz})$} & \multirow{3}{*}{$\mathrm{E}(\mathrm{eV})$} \\
\hline & & \multicolumn{4}{|l|}{ Pt } & \\
\hline & & $550^{\circ} \mathrm{C}$ & $495^{\circ} \mathrm{C}$ & $440^{\circ} \mathrm{C}$ & $385^{\circ} \mathrm{C}$ & \\
\hline 1(high) & $10 \sim 10^{4}$ & 153.7 & 104.5 & 113.9 & 5776 & 0.54 \\
\hline 2(middle) & $1 \sim 10$ & 8.05 & 5.18 & 3.83 & 4.79 & 0.583 \\
\hline 3(low) & $0.01 \sim 1$ & 0.62 & 0.37 & 0.22 & 0.19 & 0.817 \\
\hline
\end{tabular}

As can be shown in figure 12 to figure 14, the dependence of temperature on the serial resistances and polarization resistances were plotted in $800 \mathrm{ppm} \mathrm{NO}$ with $8 \% \mathrm{O}_{2}$ on two cells. Results showed that the activation energy of the serial resistance Rs which was relative to the conductivity of the electrolyte for the two electrodes were close to each other. The activation energy in each arcs were calculated according to the equation (4). The activation energy of the total polarization resistance $\mathrm{Rp}$ for the $\mathrm{Pt}-\mathrm{Ba}$ electrode and $\mathrm{Pt}$ electrode were $0.776 \mathrm{eV}$ and $1.238 \mathrm{eV}$ respectively in $800 \mathrm{ppm}$ $\mathrm{NO}$ with $8 \% \mathrm{O}_{2}$. The results were very close to the results obtained in the pure $8 \% \mathrm{O}_{2}$ atmosphere. And the activation energy were $0.817 \mathrm{eV}$ and $1.333 \mathrm{eV}$ for the $\mathrm{Pt}-\mathrm{BaO}$ electrode and $\mathrm{Pt}$ electrode. This results were very close to the $\mathrm{O}_{2}$ reduction reaction activation energy on $\mathrm{Pt}$ electrode studied by Bauerle [31]. And the value was between $1.43 \mathrm{eV}$ and $1.78 \mathrm{eV}$. The results demonstrated that the adsorption decomposition of $\mathrm{O}_{2}$ can be the controlling reaction step.

The activation energy appeared in arc 3 in the low frequency $(0.01 \mathrm{~Hz}-1 \mathrm{~Hz})$ for the $\mathrm{Pt}-\mathrm{BaO}$ electrode and $\mathrm{Pt}$ electrode were $0.817 \mathrm{eV}$ and $1.273 \mathrm{eV}$ respectively in $\mathrm{NO}$ with $\mathrm{O}_{2}$ atmosphere. While in 800ppm $\mathrm{NO}$, the values were $0.987 \mathrm{eV}$ and $1.473 \mathrm{eV}$ and the values in $8 \% \mathrm{O}_{2}$ were $0.858 \mathrm{eV}$ and $1.413 \mathrm{eV}$ respectively indicating the $\mathrm{NO}$ or $\mathrm{O}_{2}$ related reaction processes were included in this region. The activation energy in $\mathrm{NO}$ with $\mathrm{O}_{2}$ appeared the lowest. The activation energy values in this frequency range were close to the results shown by Hansen [25, 29, 32]. As can be obtained from the results, the $\mathrm{Pt}-\mathrm{BaO}$ electrode showed lower activation energy than the $\mathrm{Pt}$ electrode. The resistances varied less with the temperature in the $\mathrm{Pt}-\mathrm{BaO}$ electrode. This may be controlled by the diffusion process of the reactants in the electrode. Therefore, the processes appeared in arc 3 may be related with the adsorption, surface diffusion, transfer of $\mathrm{O}_{2}$ and NOx intermediates near/at the triple phase boundary (TPB). and the dissociative adsorption of $\mathrm{O}_{2}$.

The activation energy for the $\mathrm{Pt}-\mathrm{Ba}$ electrode and $\mathrm{Pt}$ electrode in the high frequency $\left(\operatorname{arc} 1,10 \mathrm{~Hz}-10^{4} \mathrm{~Hz}\right)$ were $0.54 \mathrm{eV}$ and $0.574 \mathrm{eV}$ respectively in $\mathrm{NO}$ with $\mathrm{O}_{2}$. The values were close to each other in three different atmospheres on two cells. The reaction processes in high frequency arc were related to the diffusion of oxide ions to the electrode/electrolyte interface and charge transfer of oxide ions from electrode/electrolyte interface to the electrolyte [29, 33]. The activation energy in the middle frequency (arc 2, $1 \mathrm{~Hz} \sim 10 \mathrm{~Hz}$ ) may be attributed to the charge transfer reactions in the electrode and the adsorption decomposition of $\mathrm{O}_{2}$ cause the activation energy were between the high and low frequency range. The activation energy were $0.583 \mathrm{eV}$ and $0.941 \mathrm{eV}$ for the $\mathrm{Pt}-\mathrm{BaO}$ electrode and $\mathrm{Pt}$ electrode in $\mathrm{NO}$ with $\mathrm{O}_{2}$.

Results showed that the decrease of activation energy in the middle and low frequency range became more significant in the $\mathrm{Pt}-\mathrm{BaO}$ electrode. The improvement of the reaction performance may have relations with the processes of $\mathrm{NO}$ oxidation to $\mathrm{NO}_{2}$, NOx storage in the form of $\mathrm{Ba}\left(\mathrm{NO}_{3}\right)_{2}$, and the $\mathrm{Ba}\left(\mathrm{NO}_{3}\right)_{2}$ decomposition to $\mathrm{N}_{2}$ with external electrical field. The analysis of the experiments was consistent with the polarization results in $\mathrm{I}-\mathrm{V}$ curves and $\mathrm{CV}$ tests. Thus, the proposed mechanism in $\mathrm{Pt}-\mathrm{BaO}$ electrode can be described in figure 15: $\mathrm{NO}$ can be oxidized to $\mathrm{NO}_{2}$ on the Pt surface. And $\mathrm{NO}$ and $\mathrm{NO}_{2}$ can be stored in the adsorption layer in the form of $\mathrm{Ba}\left(\mathrm{NO}_{3}\right)_{2}$. The decomposition of $\mathrm{Ba}\left(\mathrm{NO}_{3}\right)_{2}$ under polarization decreases the reaction path of $\mathrm{NO}$ electrochemical reduction.

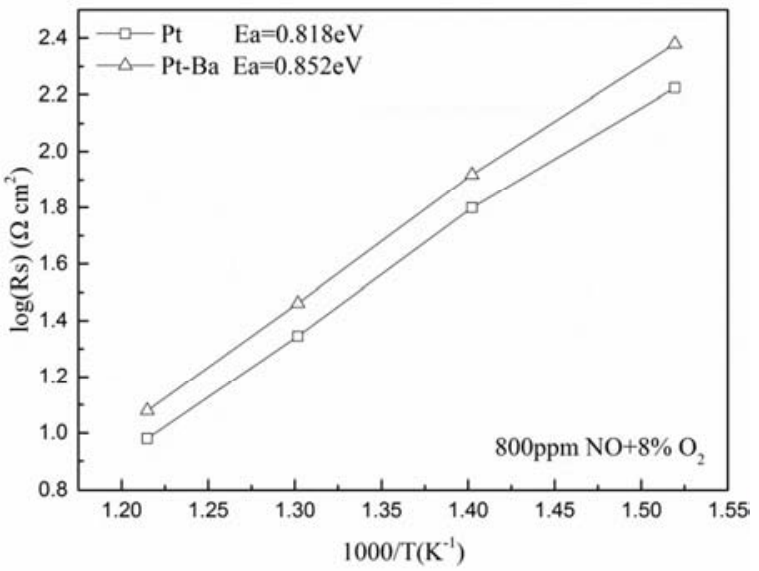

Figure 12. Serial resistances(Rs) for the Pt-BaO electrode and Pt electrode in 800 ppm NO with $8 \%$.

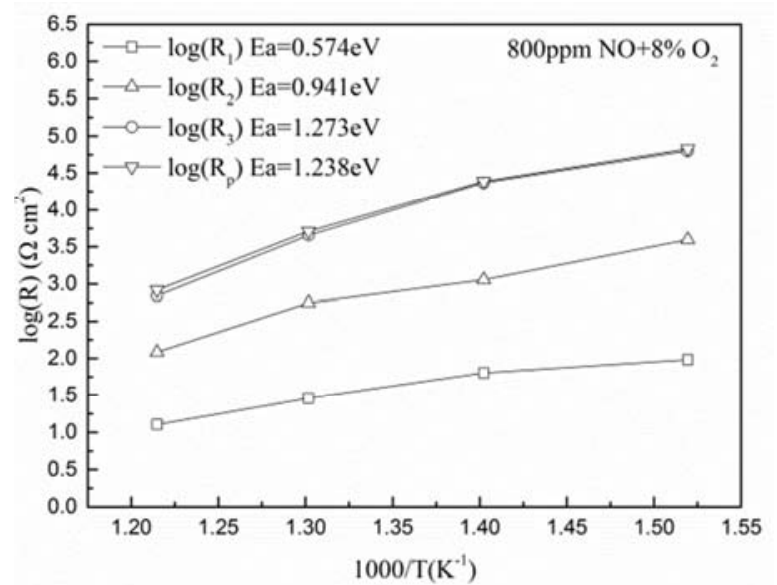

Figure 13. Polarization resistances $\left(R_{p}\right)$ for the Pt electrode in $800 \mathrm{ppm} \mathrm{NO}$ with $8 \% \mathrm{O}_{2}$. 


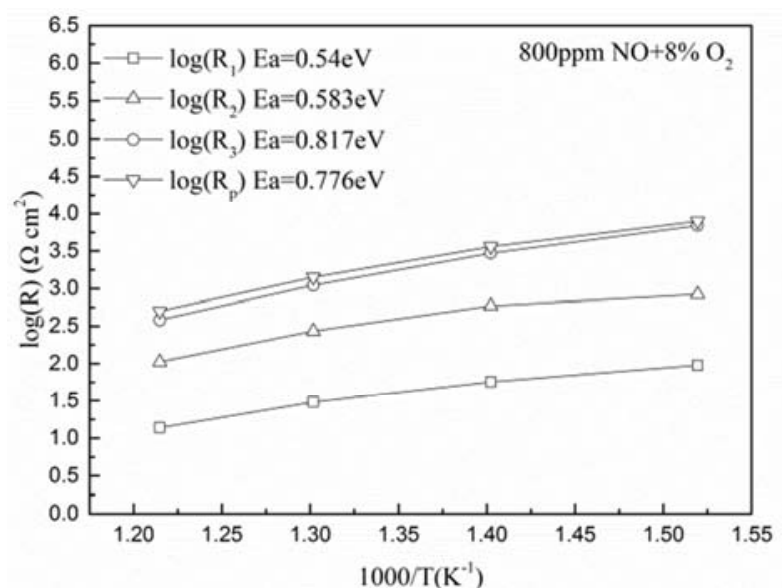

Figure 14. Polarization resistances $\left(R_{p}\right)$ for the Pt-BaO electrode in $800 \mathrm{ppm}$ $\mathrm{NO}$ with $8 \% \mathrm{O}_{2}$.

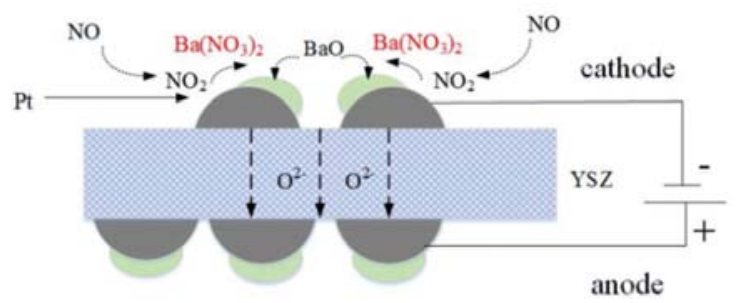

$$
\text { Cathode : } \begin{aligned}
& \mathrm{NO}+2 e^{-} \rightarrow \frac{1}{2} \mathrm{~N}_{2}+\mathrm{O}^{2-} \quad 2 \mathrm{NO}+\mathrm{BaO}+\frac{3}{2} \mathrm{O}_{2} \rightarrow \mathrm{Ba}\left(\mathrm{NO}_{3}\right)_{2} \\
& \mathrm{NO}_{2}+4 e^{-} \rightarrow \frac{1}{2} \mathrm{~N}_{2}+2 \mathrm{O}^{2-} \quad 2 \mathrm{NO}_{2}+\mathrm{BaO}+\frac{1}{2} \mathrm{O}_{2} \rightarrow \mathrm{Ba}\left(\mathrm{NO}_{3}\right)_{2} \\
& \mathrm{Ba}\left(\mathrm{NO}_{3}\right)_{2}+10 e^{-} \rightarrow \mathrm{BaO}+\mathrm{N}_{2}+5 \mathrm{O}^{2-}
\end{aligned}
$$

Anode: $2 \mathrm{O}^{2-} \rightarrow \mathrm{O}_{2}+4 e^{-}$

Figure 15. The proposed improved reaction mechanism of NO electrochemical reduction in Pt-BaO electrode.

\section{Conclusion}

The NO electrochemical reduction performances on the $\mathrm{Pt}$ electrode and the $\mathrm{Pt}-\mathrm{BaO}$ electrode were studied by linear sweep voltammetry and CV tests. Results showed that the $\mathrm{Pt}-\mathrm{BaO}$ electrode showed better activity and selectivity than the $\mathrm{Pt}$ electrode in $\mathrm{NO}$ atmosphere according to the $\mathrm{CV}$ measurements and I-V polarization curves. The electrochemical performance of $\mathrm{NO}$ on $\mathrm{Pt}-\mathrm{BaO}$ electrode was superior to that on Pt electrode.

Electrochemical impedance spectra results showed that the resistances obtained on $\mathrm{Pt}-\mathrm{BaO}$ electrode were far smaller than the results in the $\mathrm{Pt}$ electrode. The resistances in the $\mathrm{O}_{2}$ containing atmospheres were larger than the pure NO atmosphere in two cells at high temperatures. The resistance in the $\mathrm{NO}$ with $\mathrm{O}_{2}$ atmosphere decreased more significantly with $\mathrm{Ba}$ adsorption layer which was mainly ascribed to the acceleration of the surface diffusion, adsorption decomposition of $\mathrm{O}_{2}$ and transfer of the $\mathrm{O}_{2} / \mathrm{NO}$ components near/at the TPB. The activation energy in Pt-BaO electrode were lower than the $\mathrm{Pt}$ electrode in three different atmospheres. The proposed mechanism may be concluded as: $\mathrm{NO}$ can be oxidized to $\mathrm{NO}_{2}$ on the Pt surface. And $\mathrm{NO}$ and
$\mathrm{NO}_{2}$ can be stored in the adsorption layer in the form of $\mathrm{Ba}$ $\left(\mathrm{NO}_{3}\right)_{2}$. The decomposition of $\mathrm{Ba}\left(\mathrm{NO}_{3}\right)_{2}$ under polarization decreases the reaction path of $\mathrm{NO}$ electrochemical reduction. Adding Ba adsorption layer can trap NO in the active sites and thus the NO removal performance can be strengthened.

\section{References}

[1] J. C. Summers, S. V. Houtte, D. Psaras. Simultaneous control of particulate and NO emissions from diesel engines $[\mathrm{J}]$. Applied Catalysis B: Environment, 1996, 10: 139-156.

[2] M. T. Lerdau, J. W. Munger, J. D. Jacob, "The $\mathrm{NO}_{2}$ flus conundrum [J]," Science, 2000, 289: 2291-2293.

[3] Z. M. He, K. B. Andersen, L. Keel, F. B. Nygaard, M. Menon, K. K. Hansen. Processing and characterization of porous electrochemical cells for flue gas purification [J]. Ionics, 2009, 15: 427-431.

[4] T. J. Huang, C. Y. Wu, S. H. Hsu, C. C. Wu. Complete emissions control for highly fuel-efficient automobiles via a simulated stack of electrochemical-catalytic cells [J]. Energy \& Environmental Science, 2011, 4: 4061-4067.

[5] T. J. Huang, C. Y. Wu, C. C. Wu. Lean-burn NOx emission control via simulated stack of solid oxide fuel cells with $\mathrm{Cu}$-added $(\mathrm{LaSr}) \mathrm{MnO}_{3}$ cathodes [J]. Chemical Engineering Journal, 2011, 172 (2-3): 665-670.

[6] M. Awano, Y. Fujishiro, K. Hamamoto. Advances in nano-structured electrochemical reactors for NOx treatment in the presence of oxygen [J]. International Journal of Applied Ceramic Technology, 2004, 1 (3): 277-286.

[7] K. K. Hansen. Solid state electrochemical DeNOx-An overview [J]. Applied Catalysis B: Environmental, 2010, 100 (3-4): 427-432.

[8] T. J. Huang, C. Y. Wu, D. Y. Chiang, C. C. Yu. Ambient temperature NOx emission control for lean-burn engines by electro-catalytic tubes [J]. Applied Catalysis A: General, 2012, 445-446: 153-158.

[9] T. J. Huang, C. L. Chou. Feasibility of simultaneous NO reduction and electricity generation in SOFCs with $\mathrm{V}_{2} \mathrm{O}_{5}$ or $\mathrm{Cu}$ added LSCF-GDC cathodes [J]. Electrochemistry Communications, 2009, 11 (2): 477-480.

[10] R. M. L. Werchmeister, K. K. Hansen. Electrochemical reduction of oxygen and nitric oxide at low temperature on $\mathrm{Ce}_{1-\mathrm{x}} \mathrm{Pr}_{\mathrm{x}} \mathrm{O}_{2-\delta}$ cathodes [J]. Electrochimica Acta, 2013, 114: 474-477.

[11] T. J. Huang, C. Y. Wu, Y. H. Lin. Electrochemical enhancement of nitric oxide removal from simulated lean-burn engine exhaust via solid oxide fuel cells [J]. Environmental Science \& Technology, 2011, 45: 5683-5688.

[12] K. K. Hansen, E. M. Skou, H. Christensen. Perovskites as cathodes for nitric oxide reduction [J]. Journal of The Electrochemical Society, 2000, 147 (5): 2007-2012.

[13] C. G. Schmidt, D. Ippolito, J. J. Bentzen, K. B. Andersen, A. Kaiser, K. K Hansen. Fabrication and characterization of multi-layer ceramics for electrochemical flue gas purification [J]. Journal of The Electrochemical Society, 2013, 160 (9): E113-E119. 
[14] A. de Lucas-Consuegra, A. Caravaca, M. J. Martín de Vidales, F. Dorado, S. Balomenou, D. Tsiplakides, P. Vernoux, J. L. Valverde. An electrochemically assisted NOxstorage/reduction catalyst operating under fixed lean burn conditions [J]. Catalysis Communications, 2009, 11 (4), 247-251.

[15] J. Shao, K. K. Hansen. Optimization of an electrochemical cell with an adsorption layer for NOx removal [J]. Journal of Solid State Electrochemistry, 2012, 16 (10): 3331-3340.

[16] R. M. L. Werchmeister, K. K. Hansen, M. Mogensen. Electrochemical removal of NOx with porous cell stacks[J]. Materials Research Bulletin, 2010, 45: 1554-1561.

[17] S. Bredikhin, K. Maeda, M. Awano. Electrochemical cell with two layers cathode for NO decomposition [J]. Ionics, 2001, 7 (1-2): 109-115.

[18] S. Bredikhin, K. Maeda, M. Awano. NO decomposition by an electrochemical cell with mixed oxide working electrode [J]. Solid State Ionics, 2001, 144 (1-2): 1-9.

[19] S. Bredikhin, K. Maeda, M. Awano. Low current density electrochemical cell for NO decomposition [J]. Solid State Ionics, 2002, 152-153: 727-733.

[20] K. Hamamoto, Y. Fujishiro, M. Awano. Low-temperature NOx decomposition using an electrochemical reactor [J]. Journal of The Electrochemical Society, 2008, 155 (8): E109-E111.

[21] X. Li, P. Vernoux. A new NOx storage-reduction electrochemical catalyst [J]. Applied Catalysis B: Environmental, 2005, 61 (3-4): 267-273.

[22] W. Y. Hernandez, A. Hadjar, A. Giroir-Fendler, P. Andy, A. Princivalle, M. Klotz, A. Marouf, C. Guizard, C. Tardivat, C. Viazzi, P. Vernoux. Electrochemically-assisted NOx storage-reduction catalysts [J]. Catalysis Today, 2015, 241: 143-150.

[23] C. G. Vayenas, S. Bebelis, S. Ladas. Dependence of catalytic rates on catalyst work function [J]. Nature, 1990, 343: 625-627.
[24] A. A. Nikola. NEMCA-From discovery to technology [J]. Catalysis Today, 2009, 146: 308-311.

[25] M. L. Traulsen, K. K. Hansen. Improvement of LSM15-CGO10 electrodes for electrochemical removal of $\mathrm{NOx}$ by $\mathrm{KNO}_{3}$ and $\mathrm{MnO}_{\mathrm{x}}$ impregnation [J]. Journal of The Electrochemical Society, 2011, 158 (12): P147-P161.

[26] M. L. Traulsen, F. Bræstrup, K. K. Hansen. NOx conversion on porous LSF15-CGO10 cell stacks with $\mathrm{KNO}_{3}$ or $\mathrm{K}_{2} \mathrm{O}$ impregnation [J]. Journal of Solid State Electrochemistry, 2012, 16: $2651-2660$

[27] M. L. Traulsen, K. B. Andersen, K. K. Hansen. NOx conversion on LSM15-CGO10 cell stacks with $\mathrm{BaO}$ impregnation [J]. Journal of Materials Chemistry, 2012, 22: $11792-11800$

[28] J. Shao, K. K, Hansen. Electrochemical NOx reduction on an LSM/CGO symmetric cell modified by NOx adsorbents [J]. Journal of Materials Chemistry A, 2013, 1: 7137-7146.

[29] J. Shao, K. K, Hansen. Enhancement of NOx removal performance for $\left(\mathrm{La}_{0.85} \mathrm{Sr}_{0.15}\right)_{0.99} \mathrm{MnO}_{3} / \mathrm{Ce}_{0.9} \mathrm{Gd}_{0.1} \mathrm{O}_{1.95}$ electrochemical cells by NOx storage/reduction adsorption layers [J]. Electrochimica Acta, 2013, 90: 482-491.

[30] J. Shao. NOx reduction using an electrochemical cell with NOx adsorbents [D]. Denmark: Technical University of Denmark, 2013.

[31] J. E. Bauerle. Study of solid electrolyte polarization by a complex admittance method [J]. Journal of Physics and Chemistry of Solids, 1969, 30 (12): 2657-2670.

[32] R. M. L. Werchmeister, K. K. Hansen, M. Mogensen. Chracterization of $\left(\mathrm{La}_{1-\mathrm{x}} \mathrm{Sr}_{\mathrm{x}}\right)_{\mathrm{S}} \mathrm{MnO}_{3}$ and doped ceria composite electrodes in NOx-containing atmosphere with impedance spectroscopy [J]. Journal of The Electrochemical Society, 2010, 157 (5): P35-P42.

[33] M. J. Jorgensen, M. Mogensen. Impedance of solid oxide fuel cell LSM/YSZ composite cathodes [J]. Journal of The Electrochemical Society, 2001, 148 (5): A433-A442. 